\title{
Neogene terrestrial sedimentary environments of the Orava-Nowy Targ Basin: a case study of the Oravica River section near Čimhová, Slovakia
}

\author{
Maciej ŁOZIŃSKI ${ }^{1, *}$, Anna WYSOCKA ${ }^{1}$ and Mirosław LUDWINIAK ${ }^{1}$ \\ 1 University of Warsaw, Faculty of Geology, Żwirki i Wigury 93, 02-089 Warszawa, Poland
}

Łoziński, M., Wysocka, A., Ludwiniak, M., 2015. Neogene terrestrial sedimentary environments of the Orava-Nowy Targ Basin: a case study of the Oravica River section near Čimhová, Slovakia. Geological Quarterly, 59 (1): 21-34, doi: 10.7306/gq.1209

The Orava-Nowy Targ Basin is an intramontane depression located at the border of the Inner and Outer Carpathians. It is filled mostly with fine-grained terrestrial and fresh-water deposits of Neogene and Quaternary age, which record the structural evolution and denudation processes of the surrounding regions: Orava, Podhale, and the Tatra Mts. The Orava-Nowy Targ Basin fill was studied in the Oravica River section, which reveals $90 \mathrm{~m}$ thick Neogene deposits and allows observation of their lateral diversity. Fifteen lithofacies and seven facies associations distinguished here document the depositional evolution of the basin fill, starting from hill-slope debris flow through silt turbidite-bearing lake, to flood-dominated fluvial plain, swamp and alluvial fan deposits, as well as a pyroclastic event. The palaeorelief was low during deposition and the Orava-Nowy Targ Basin could have spread significantly more to the south.

Key words: terrestrial environments, mudrocks, facies analysis, Neogene, Orava-Nowy Targ Basin, Carpathians.

\section{INTRODUCTION}

The Orava-Nowy Targ Basin (ONT Basin) is an intramontane basin straddling the junction between the Western Central and Outer Carpathians (Fig. 1A). The basin formation and the process of basin filling took place in Neogene and Quaternary, and was controlled by regional tectonic events, mainly strike-slip faulting and vertical movements of units underlying the basin. This makes the basin infill an excellent record to study the structural evolution of the adjacent areas, which include Orava, Podhale, the Tatra, Pieniny, and Beskid Żywiecki Mts., and the Orava-Nowy Targ depression (Fig. 2B). This evolution formed the present-day pattern of the main structural units represented by the Magura Unit, Pieniny Klippen Belt, Podhale Synclinorium and Tatra Block.

In the Early Miocene, the sedimentation of deposits belonging to the Magura Unit and Podhale Synclinorium generally stopped and was followed by uplift. At this time, thrusting and folding within the northern part of the Magura Unit was in progress and continued to spread southwards. During the Early/Middle Miocene the Podhale Synclinorium was folded and the tectonic contacts between the Magura Unit, Pieniny Klippen Belt, and Podhale Synclinorium were formed. The sedimentation of the ONT Basin could have started in the Middle or

\footnotetext{
* Corresponding author, e-mail: maciej.lozinski@student.uw.edu.pl
}

Received: September 27, 2013; accepted: June 28, 2014; first published online: December 29, 2014
Late Miocene (Oszast and Stuchlik, 1977) upon the weathered and eroded surface of these three units.

During the Late Neogene and Quaternary, the tectonic subsidence of the ONT Basin continued (Łój et al., 2009), while adjacent areas were generally uplifted (Watycha, 1977). This resulted in the partial erosion of the Magura Unit, Pieniny Klippen Belt, and Podhale Synclinorium, which all supplied clastic material to the ONT Basin (Tokarski et al., 2012). The clast characteristics (e.g., grain size, lithology), the type of sedimentary environment, and palaeotransport directions allow palaeorelief interpretations and reveal which units were eroded at that time. Such analysis can be applied to the ONT Basin to trace the structural evolution of the basin itself, as well as the process of uplift and erosion of the Magura Unit, Pieniny Klippen Belt, Podhale Synclinorium, and Tatra Block.

Although the Tatra Block could have already been uplifted in the Neogene (Śmigielski et al., 2011), the material derived from the Tatra Block is encountered only within the uppermost part of the ONT Basin, which is considered to be Quaternary (Watycha, 1977; Baumgart-Kotarba et al., 1996; Tokarski et al., 2012). This may reflect either a large thickness of the now non-existent Paleogene/Neogene overburden of the Tatra Massif, or the existence of a barrier separating the Tatra area from the ONT Basin (Watycha, 1977), or point to the type of weathering and transportation that resulted in fine clastic delivery only.

The main aim of the paper is to reconstruct the main sedimentary environments for the ONT basin in the Neogene, based on detailed sedimentological studies in the Oravica River section (Figs. 2-4). 


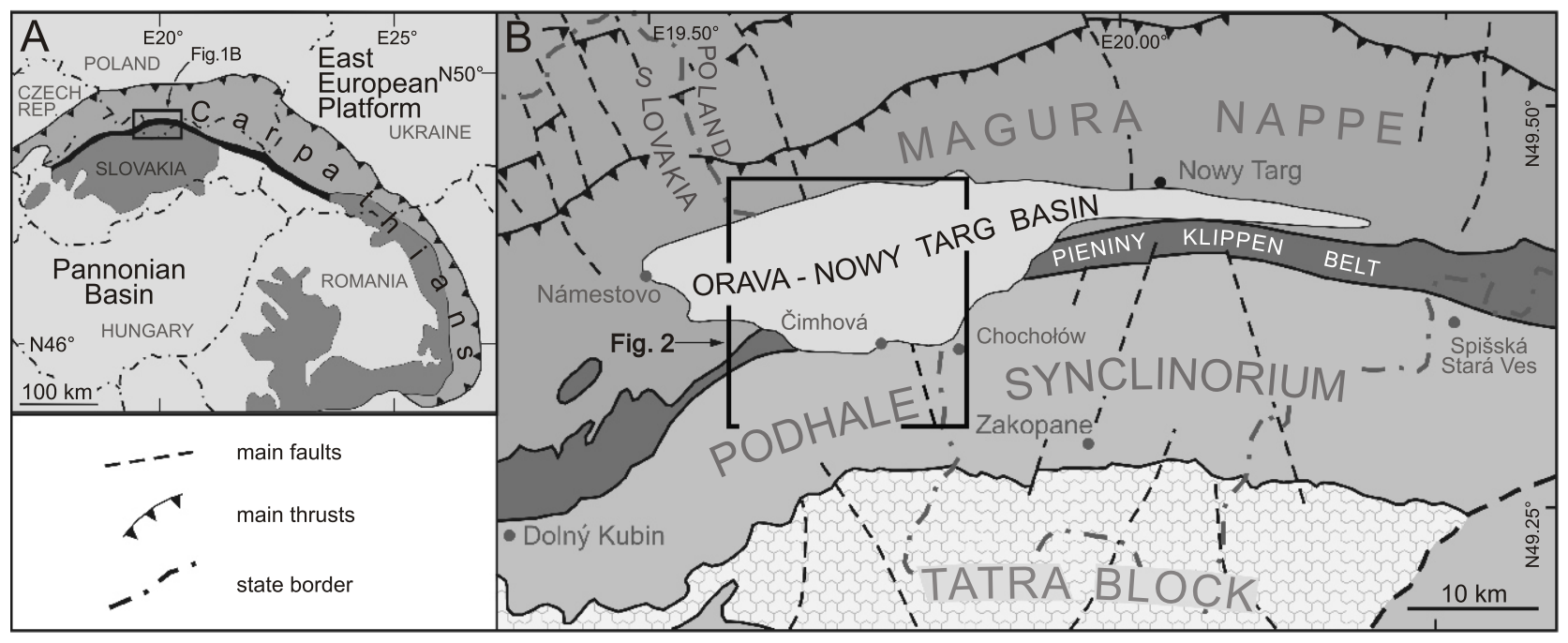

Fig. 1. Schematic tectonic map of the northern part of the Central Western Carpathians (A), showing the location of the study area (B) (after Lexa et al., 2000; modified)

\section{GEOLOGICAL SETTING}

The ONT Basin overlies three older units: the Magura Nappe, Pieniny Klippen Belt (PKB), and Podhale Synclinorium (Fig. 1B). The PKB is a narrow, long, and strongly tectonized structure comprising several successions of Early Jurassic-Paleogene rocks represented by limestones, marls, claystones, calcarenites, and conglomerates (e.g., Andrusov, 1938; Birkenmajer, 1960). The Magura Nappe succession is Albian/Cenomanian-Miocene in age and consists predominantly of greywackes, quartz and arkosic sandstones, claystones, siltstones, and marls (Birkenmajer and Oszczypko, 1989; Cieszkowski et al., 1989; Cieszkowski, 1995; Malata et al., 1996).

The ONT Basin is underlain in the study area by the Podhale Synclinorium (Fig. 2C), which is generally built up of sandstones, calcareous claystones, shales, and rare conglomerates, which comprise the Lutetian-Bartonian to Egerian sedimentary fill of the Central Carpathian Paleogene Basin (CCPB) (Gross et al., 1993a; Olszewska and Wieczorek, 1998; Sotak, 1998a, b; Garecka, 2005). The synclinorium is asymmetrical with the main parallel tectonic zones elongated in an E-W direction (Mastella, 1975; Ludwiniak, 2010). The study area is located near the northern margin of this unit (Figs. 1 and 2C), where the underlying flysch rocks dip $45-50^{\circ}$ to the south.

The generally E-W elongated ONT Basin is divided into two main parts: eastern, called the Nowy Targ Basin, and western, referred to as the Orava Basin. The western part is up to $1300 \mathrm{~m}$ deep (Watycha, 1977), $14 \mathrm{~km}$ wide, and rhomboidal in shape. The genesis of the Orava Basin has been widely discussed (Roth et al., 1963; Watycha, 1977; Bac-Moszaszwili, 1993; Baumgart-Kotarba, 1996, 2001; Pomianowski, 2003; Baumgart-Kotarba et al., 2004; Struska, 2008; Tokarski et al., 2012), but most authors agree that a strike-slip mechanism was involved. During the Late Oligocene-Miocene, the Western Carpathians structure was affected by the formation of regional fault systems (Kováč and Hók, 1993; Kováč et al., 1998). It is possible that the formation of faults bounding the ONT Basin is related to the activity of the inferred Myjava Fault (Jankủ et al., 1984; Pospíšil et al., 1986; Pospíšil, 1990).

The Neogene strata within this part of the ONT Basin are moderately tectonically disturbed within a few zones, including the Čimhová region. The dips of beds are mainly subhorizontal, but increase up to $25^{\circ}$ at the basin margin (dip direction is basinwards). The fracture network is the most distinct structural feature in the Neogene strata (Tokarski and Zuchiewicz 1998; Kukulak, 1999), whereas faults, predominantly normal in character, are rarely noticed.

The ONT Basin opened above a meso-Alpine consolidated basement which underwent weathering and erosion (Cieszkowski, 1995; Świerczewska, 2005). The onset of sedimentation is variously estimated to be Karpatian/Badenian (Nagy, 1993), Badenian (Oszast and Stuchlik, 1977), Late Badenian or Sarmatian (Cieszkowski, 1995), or Sarmatian in age (Nagy et al., 1996), and the age of the basin fill itself is equally poorly constrained. An angular unconformity dissects the upper part of the ONT Basin infill, but the age of tilting and associated erosion is still under discussion (Baumgart-Kotarba et al., 1996; Tokarski et al., 2012). Active sedimentation within the basin continues to the present-day.

The ONT Basin infill consists predominantly of fine clastic deposits represented by claystones, coaly claystones, clayey siltstones, and sandstones, whereas conglomerates are present in minor quantities (Watycha, 1977). Clay mineral studies revealed the presence of beidellite, chlorite, and illite (Wiewióra and Wyrwicki, 1980). There are also intercalations of brown coal (Kołcon and Wagner, 1991; Nagy et al., 1996) and tuffite (Sikora and Wieser, 1974; Westwalewicz-Mogilska, 1974). The basin fill has been interpreted in terms of fresh-water and terrestrial deposition, with the marginal, conglomeratic alluvial fans merging basinwards with fine clastic deposits (Watycha, 1976). Although there was discussion about the presence of Lower Miocene marine deposits in the ONT Basin (Birkenmajer, 1954), they have been finally reinterpreted as belonging to the uppermost part of the Magura Unit (Cieszkowski, 1995). So far, no detailed sedimentological papers have been published from the area, except for studies devoted to conglomerates interpreted as laid down in alluvial fan and fluvial environments (Plewa, 1969; Baumgart-Kotarba et al., 1996; Kukulak, 1998; Tokarski et al., 2012). Clastic material was generally derived from the CCPB and Magura Unit, and subordinately from the PKB. Detritus of Tatra Mts. provenance occurs only within the uppermost part of the ONT Basin fill. 


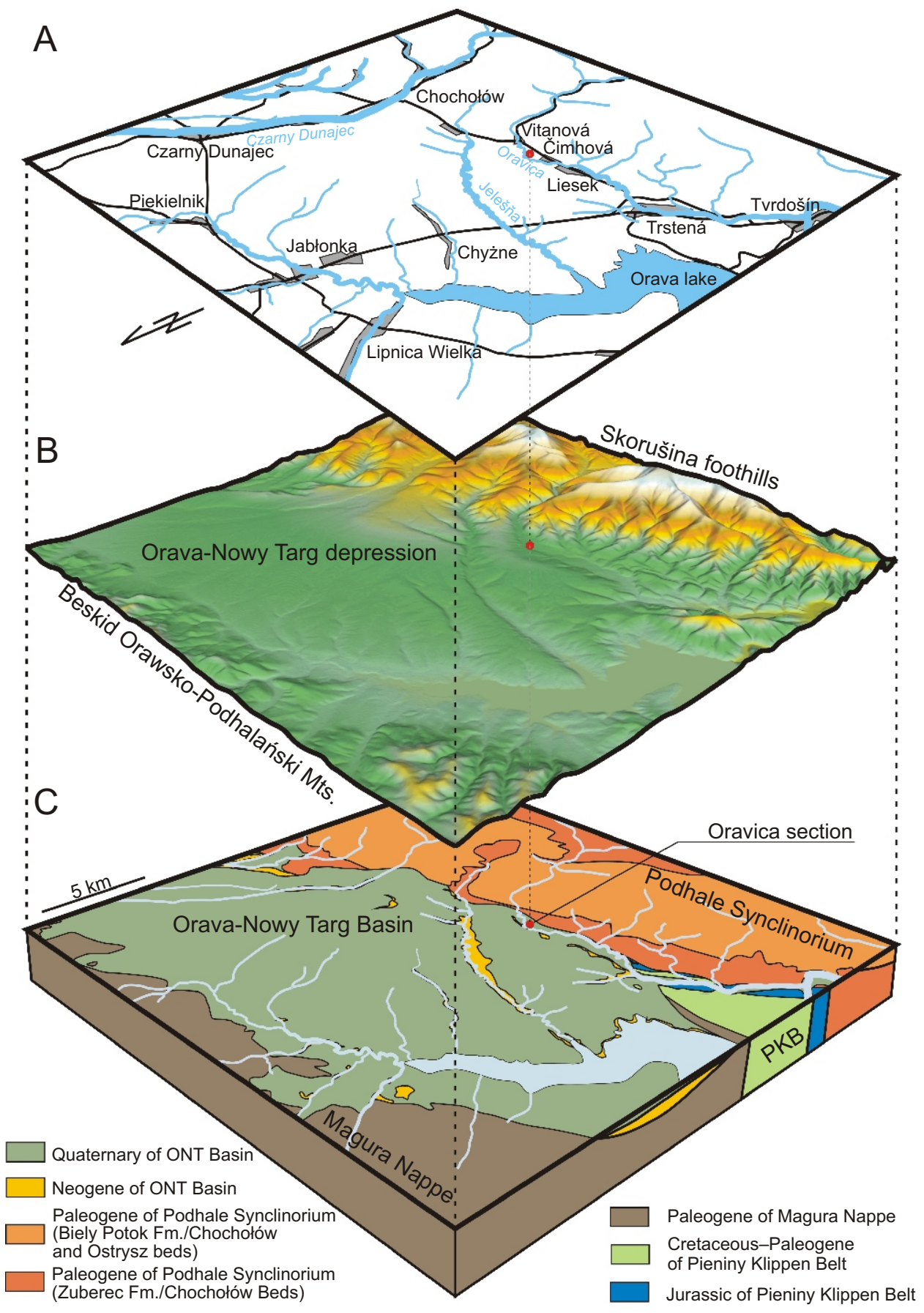

Fig. 2. Topography (A), present-day terrain morphology (B) and geological context of the Oravica River section (C)

Geological map compilation based on Lexa et al. (2000) and Gross et al. (1993b); map location is shown in Figure 1B

\section{STUDY AREA}

The Oravica River section is located at the present southern border of the ONT Basin. At the study area, near the Slovak village Čimhová, the Oravica River crosses the contact between the Central Carpathian Paleogene Basin (CCPB) and Neogene deposits of the ONT Basin (Fig. 2C). The whole river valley is $>0.5 \mathrm{~km}$ wide, and the river channel is only several metres wide. Within the section discussed the river cuts into its former ter- races and into the surrounding terrain, which is up to $15 \mathrm{~m}$ above the water level. Natural exposures of the Neogene strata are located in the river bed, cut banks, and slide scars.

The Oravica River section extends between two points where the Oravica River crosses the CCPB/ONT Basin contacts (N49.36520, E19.70532 and N49.36514 E19.69593; Fig. 3).

Assuming that the lowermost deposit of the Oravica River section comprises the basal part of the ONT Basin fill, it is probably of Badenian (Oszast and Stuchlik, 1977) or Sarmatian age (Nagy et al., 1996). 


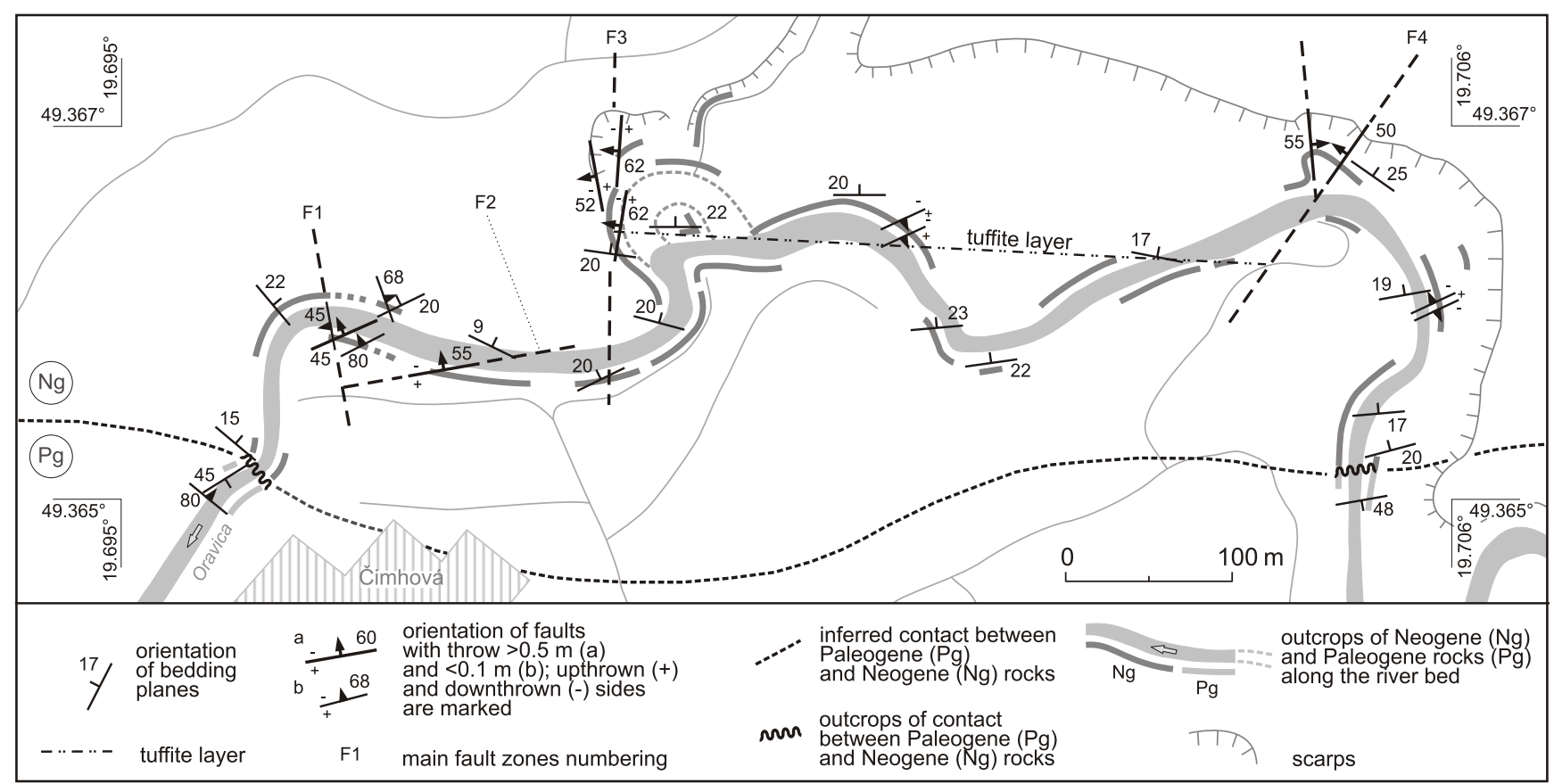

Fig. 3. Situation sketch of the Oravica River section, showing outcrops of Neogene $(\mathrm{Ng})$ and Paleogene $(\mathrm{Pg})$ rocks, and structural elements of the section

\section{METHODS}

Standard field sedimentological logging was applied to all exposures within the area discussed. Lithology, grain size, sedimentary structures, diagenetic structures, fossils, and bed thicknesses were recorded. Moreover, structural features such as bedding, fractures, and faults were measured to allow better bed correlations. Fieldwork was conducted in the years 2011-2013.

The repetitive set of sedimentary features mentioned above allows one to distinguish fourteen lithofacies, based on the methodology proposed by Reading (1996) and Miall (2000, 2006). Local conditions of deposition were interpreted for each lithofacies. Co-occurring lithofacies were grouped into seven facies associations and interpreted in terms of sedimentary environments. Facies associations were correlated across the outcrop area. Palaeoflow data comprise cross-stratum dip directions derived from cross-bedded sandstones (11 readings) and ripple cross-lamination measured on oriented samples (41 readings), with an accuracy of ca. $\pm 15^{\circ}$.

\section{RESULTS}

\section{STRUCTURAL ASPECTS}

\section{OF THE ORAVICA RIVER SECTION}

The Oravica River and its small tributaries cut into the Neogene rocks, resulting in many exposures scattered within a $500 \mathrm{x}$ $160 \mathrm{~m}$ area, elongated in an $\mathrm{E}-\mathrm{W}$ direction. The mean bedding orientation is $005^{\circ} / 20^{\circ}$ (35 measurements, standard deviations for dip direction and dip angle are $23^{\circ}$ and $4^{\circ}$, respectively). The Oravica River section allows documentation of a $90 \mathrm{~m}$ thick sedimentary log (Fig. 4) and its $500 \mathrm{~m}$ wide lateral diversity.

Rocks in the Oravica River section are moderately tectonically disturbed (Fig. 3), which is significant in terms of the whole ONT Basin. Two types of fracture were identified: 1 - regular, vertical, and NE-SW trending (see Fig. 7F); 2 - irregular, curved, near-vertical, and trending in various directions. Fracture distri- bution varies strongly within the section, which probably demonstrates a high diversity of rock mechanical properties related to their lithology. Faulting affects many parts of the section and was taken into account when doing bed correlation (Fig. 3). Fault surfaces are generally straight and accompanied by thin (several millimetre) clay-smear zones. Slickenside striations (Fig. $7 \mathrm{H}$ ) are rare and no drag folding was observed. Most faults are smallscale (throw $<0.1 \mathrm{~m}$; Fig. $7 \mathrm{G}$ ) and can be missed if bedding is indistinct. Large-scale faults (throw $>0.5 \mathrm{~m}$; Fig. 7l) can be easily spotted due to contrasts in rock colour, or the presence of displaced coal layers. Fault planes are generally steep (dip is around $45-80^{\circ}$ ), with the observed hanging-walls displaced downwards, so all faults were interpreted as normal faults.

Large-scale faults were grouped into four fault zones: F1-F4 (Fig. 3). They divide the outcrop into four areas and each of them represents a continuous part of the Oravica River sedimentary section. The area west of F1 represents the lowermost part of the section. The area between F1 and F3 also represents some lowermost part, but the exact position is uncertain. The area between F3 and F4 represents the middle and uppermost part, and the area east of F4 represents the lowermost and middle part of the section.

A tuffite layer occurs in the middle of the Oravica River section and provides an excellent stratigraphic marker across the study area (Figs. 3 and 8 ). The tuffite has a constant thickness (ca. $40 \mathrm{~cm}$ ) and displays a characteristic tripartition in its internal structure (Fig. 7C), so it can be confidently traced in the field. The tuffite is easily accessible and was observed at six separate places, which points to the absence of any major faults between the known tuffite exposures (between fault zones F3 and F4; see Fig. 3).

\section{LITHOFACIES}

Fifteen lithofacies were distinguished in the Oravica River section (Table 1).

Matrix-supported monomict disorganized breccia (Fig. $5 \mathrm{~A}, \mathrm{~B}$ ) consists of flysch sandstone and mudstone clasts (up to 


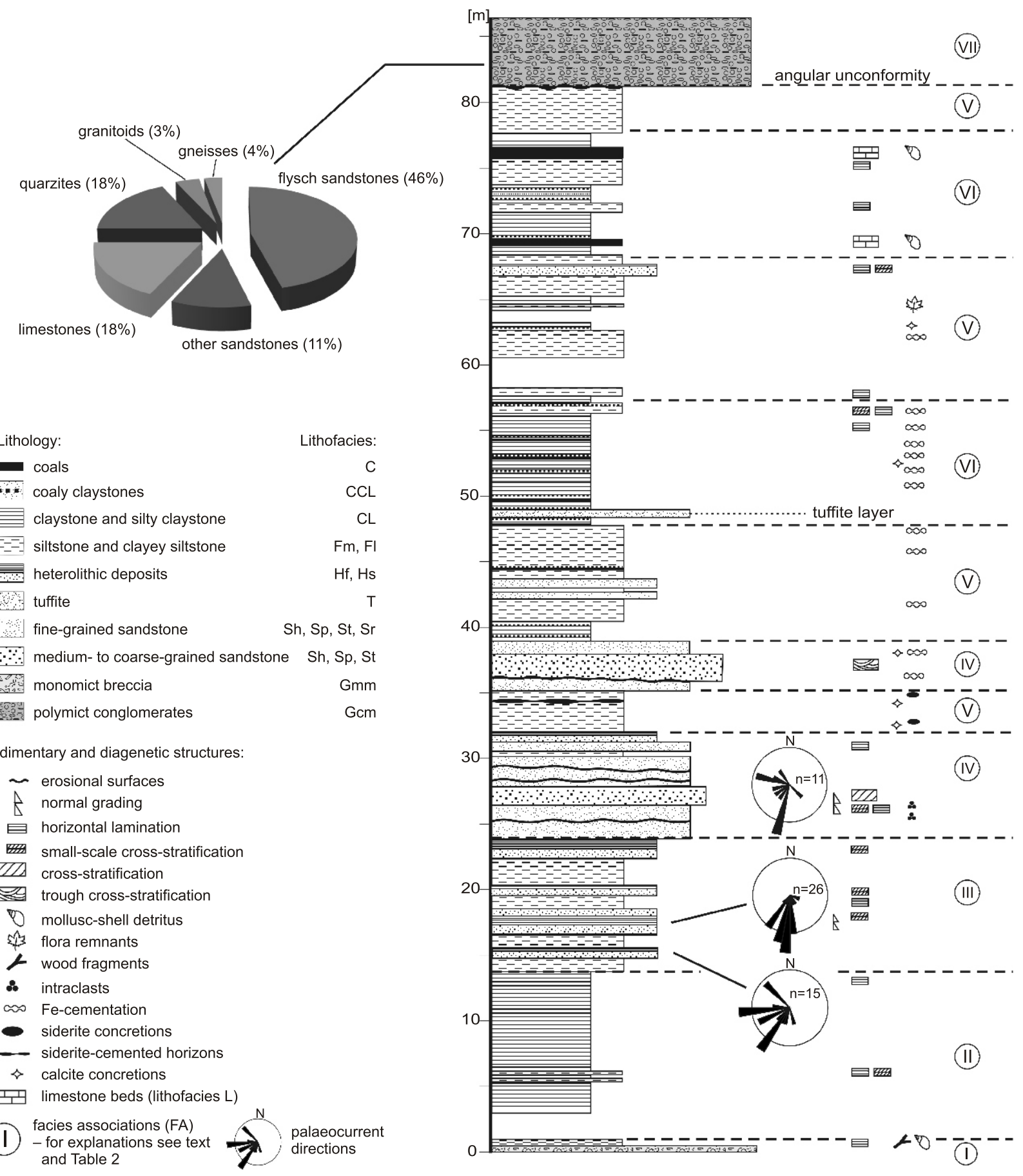

Fig. 4. Synthetic sedimentary log for the Oravica River section, showing lithology, lithofacies, facies associations, sedimentary and diagenetic structures, and palaeocurrent directions

$0.4 \mathrm{~m}$ across) set in an abundant muddy matrix. Clasts are very poorly sorted, weathered, often fractured, and angular in shape. Contacts between the clasts and the matrix are obscured by a similarity in colour and the low mechanical strength of the clasts. No sedimentary structures were found. Such structureless, matrix-supported breccia can be interpreted as the result of deposition from a cohesive, clay-rich debris flow (Miall, 2006). Any tectonic origin of the breccia is discarded here because of the absence of slip structures. This lithofacies was observed only at the base of the Oravica River section, where the breccia bed is around $2 \mathrm{~m}$ thick.

Clast-supported polymict conglomerate (Fig. 5C, D) shows interstices between clasts filled with unsorted sand and mud. The gravel fraction is moderately sorted and consists of pebble- to cobble-sized clasts, up to $20 \mathrm{~cm}$ in size, which are subrounded and rarely imbricated. The conglomerate occurs only at the top of the Oravica River section, where it is $5 \mathrm{~m}$ thick and underlain by an angular unconformity.

The clast composition of the conglomerate (count of 100 clasts; Fig. 4) shows a heterogeneous mixture of rocks derived from the Podhale flysch and Tatra Mountains (including their crystalline core), which is typical only of conglomerates from the uppermost part of the ONT Basin fill. Tokarski et al. (2012) performed a study of clast composition of a similar conglomerate bed in a nearby outcrop. Their results show a much higher proportion of rocks derived from the Podhale flysch relative to 
Lithofacies distinguished in the Oravica River section, with their key features and interpretation (for details see text)

\begin{tabular}{|c|c|c|c|}
\hline $\begin{array}{l}\text { Facies } \\
\text { code }\end{array}$ & Lithofacies & Description & Depositional mechanism \\
\hline $\mathrm{Gmm}$ & $\begin{array}{l}\text { matrix-supported, } \\
\text { monomict, } \\
\text { disorganized breccia }\end{array}$ & $\begin{array}{c}\text { up to } 2 \mathrm{~m} \text { thick; composed of weathered, fractured, } \\
\text { angular clasts of flysch sandstone and mudstone } \\
\text { with a muddy matrix }\end{array}$ & cohesive, clay-rich debris flow \\
\hline $\mathrm{Gcm}$ & $\begin{array}{l}\text { clast-supported } \\
\text { polymict conglomerate }\end{array}$ & $\begin{array}{c}\text { up to } 5 \mathrm{~m} \text { thick; disorganized, rare imbricated clasts; clast } \\
\text { compositon (Fig. } 4) \text { : flysch sandstones }(46 \%), \\
\text { other sandstones (11\%), limestones (18\%), } \\
\text { quartzites (18\%), gneisses (4\%), granitoids }(3 \%)\end{array}$ & low sediment concentration flow \\
\hline Sh & $\begin{array}{l}\text { horizontally laminated } \\
\text { sandstone }\end{array}$ & $\begin{array}{l}\text { beds up to } 3 \mathrm{~m} \text { thick; fine- and medium-grained, well-sorted sand- } \\
\text { stone; very common plant detritus; rare muddy intraclasts }\end{array}$ & $\begin{array}{l}\text { plane-bed transport by tractional } \\
\text { currents in upper flow regime }\end{array}$ \\
\hline Sp & $\begin{array}{l}\text { planar cross-bedded } \\
\text { sandstone }\end{array}$ & $\begin{array}{l}\text { beds up to } 1 \mathrm{~m} \text { thick; fine- and medium-grained, well-sorted } \\
\text { sandstone; very common plant detritus; rare muddy intraclasts }\end{array}$ & $\begin{array}{l}\text { 2D dune transport in upper range } \\
\text { of lower flow regime }\end{array}$ \\
\hline St & $\begin{array}{c}\text { trough cross-bedded } \\
\text { sandstone }\end{array}$ & $\begin{array}{c}\text { beds up to } 1 \mathrm{~m} \text { thick; fine- to coarse-grained; } \\
\text { occasionally filling erosional scours }\end{array}$ & $\begin{array}{l}\text { 3D dune transport in upper range } \\
\text { of lower flow regime }\end{array}$ \\
\hline $\mathrm{Sr}$ & $\begin{array}{l}\text { ripple cross-laminated } \\
\text { sandstone }\end{array}$ & beds up to $5 \mathrm{~cm}$ thick; fine-grained sandstone & $\begin{array}{l}\text { ripple transport in lower range of } \\
\text { lower flow regime }\end{array}$ \\
\hline Hs & $\begin{array}{l}\text { sandstone-dominated } \\
\text { heterolithic deposit }\end{array}$ & $\begin{array}{l}\text { cyclically organized units up to } 2 \mathrm{~m} \text { thick, of normally graded fine } \\
\text { sandstones, siltstones, and very rarely claystones; } \\
\text { small scale (up to } 10 \mathrm{~cm} \text { ) Bouma sequences Tb-e }\end{array}$ & low-density turbidity currents \\
\hline $\mathrm{Hf}$ & $\begin{array}{l}\text { siltstone-dominated } \\
\text { heterolithic deposit }\end{array}$ & $\begin{array}{l}\text { cyclically organized units up to } 2 \mathrm{~m} \text { thick, of normally graded } \\
\text { siltstones with rare interbeds of claystones; small-scale } \\
\text { (up to } 4 \mathrm{~cm} \text { ) Bouma sequences Tc-e; pillar and dish structures }\end{array}$ & low-density turbidity currents \\
\hline $\mathrm{FI}$ & laminated siltstone & $\begin{array}{l}\text { beds up to } 3 \mathrm{~m} \text { thick; siltstone and clayey siltstone; } \\
\text { laminae ca. } 1 \mathrm{~cm} \text { thick; seen as gradual colour changes }\end{array}$ & $\begin{array}{l}\text { weak current-driven fallout } \\
\text { of hemipelagic suspension }\end{array}$ \\
\hline $\mathrm{Fm}$ & massive siltstone & $\begin{array}{c}\text { beds up to } 4 \mathrm{~m} \text { thick; siltstone and clayey siltstone; generally } \\
\text { massive, locally horizontal lamination and ripple cross-lamination; } \\
\text { grey-blue or red; rare muddy intraclasts, mollusc shell } \\
\text { detritus and plant matter; siderite concretions, siderite } \\
\text { horizons, and pedogenic structures in places }\end{array}$ & $\begin{array}{l}\text { mud-suspension fallout } \\
\text { influenced by weak-currents; } \\
\text { occasionally pedogenic } \\
\text { processes }\end{array}$ \\
\hline$C L$ & massive claystone & $\begin{array}{c}\text { beds } 0.1-8.0 \mathrm{~m} \text { thick; massive to locally laminated claystone, } \\
\text { dark grey or grey-blue }\end{array}$ & deposition from suspension \\
\hline CCL & coaly claystone & $\begin{array}{c}\text { beds up to } 20 \mathrm{~cm} \text { thick of black claystones rich in dispersed } \\
\text { coalified plant matter }\end{array}$ & $\begin{array}{l}\text { phytogenic accumulation affected } \\
\text { by fine clastic supply }\end{array}$ \\
\hline C & coal & $\begin{array}{c}\text { beds up to } 30 \mathrm{~cm} \text { thick of black coal; massive or laminated, } \\
\text { brittle, shining }\end{array}$ & phytogenic accumulation \\
\hline $\mathrm{T}$ & tuffite & $\begin{array}{c}\text { approx. } 40 \mathrm{~cm} \text { thick layer comprised of } 3 \text { amalgamated cycles, } \\
\text { each grading upwards from thick siltstone to thin claystone; white } \\
\text { or yellow; green when wet }\end{array}$ & volcanic ashfall \\
\hline L & limestone & $\begin{array}{c}\text { up to } 30 \mathrm{~cm} \text { thick bed of calcitic rock; massive to laminated, } \\
\text { abundant mollusc shells; overlying coal }\end{array}$ & authigenic calcite precipitation \\
\hline
\end{tabular}

those from the Tatra Mts., while the relative share of various lithologies supplied from the Tatra Mts. is similar. The clast-supported polymict conglomerate is interpreted as a result of bedload transport in turbulent water flow typical of rivers. Only the coarsest clasts undergo deposition in mainstream flow, while finer clasts infiltrate the space between, in lower velocity flow.

Horizontally laminated sandstone consists of well-sorted, fine- and medium-grained sandstones. Laminae are delineated by concentrations of plant detritus and accentuated by mechanical weathering (Fig. 5F). The sandstone Sh often consists of rounded muddy intraclasts up to $1 \mathrm{~cm}$ across. Beds of this facies are up to $3 \mathrm{~m}$ thick and occur as single, non-amalgamated bodies within fine-grained and heterolithic lithologies. The invariability of grain-size and type of bedform demonstrates stable conditions of flow during plane-bed transport and sedimentation.

Planar cross-bedded sandstone comprises also wellsorted, fine- and medium-grained sandstones, but shows angular and tangential cross-stratification. Individual cross-sets, up to $0.4 \mathrm{~m}$ thick, are stacked vertically to form cosets up to $1 \mathrm{~m}$ thick (Fig. 5E), which are separated by either erosional boundaries or plane parallel laminasets. The Sp lithofacies is interpreted as river bedload deposits emplaced within 2D dunes. The occurrences of the planar cross-stratified sandstones are limited later- ally within the Oravica River outcrop (elongated in an E-W direction), so they are probably channel infills.

Trough cross-bedded sandstone (Fig. 5E) is similar to planar cross-bedded sandstone (Sp) and differs from the latter in the presence of concave-up basal scours. Beds are up to $1 \mathrm{~m}$ thick, show upwards fining in the grain-size from coarse to fine sand, and consists of stacked cross-sets, up to $0.5 \mathrm{~m}$ thick. This facies is interpreted as a river bedload deposit emplaced within 3D dunes.

Ripple cross-laminated sandstone occurs in thin beds (up to $5 \mathrm{~cm}$ ), which show small-scale (up to $1 \mathrm{~cm}$ ) cross-lamination. Climbing ripples occur sporadically. This lithofacies is a result of lower flow regime deposition, sometimes with a high rate of clastic material supply.

Sandstone-dominated heterolithic deposit represents vertical stacks (beds up to $2 \mathrm{~m}$ thick) of Bouma sequences (divisions $\mathrm{Tb}-\mathrm{e}$, up to $10 \mathrm{~cm}$ thick; Fig. 5G, H). The dominating grain size for $\mathrm{Tb}-\mathrm{d}$ is from fine sand to silt. The Bouma Te division can be siltstone or claystone, up to $4 \mathrm{~cm}$ thick, which was occasionally scoured at the top by the next cycle flow (Fig. 6A). Sandstone soles are erosional or show load structures (Fig. $6 \mathrm{~B}$ ). The admixture of plant detritus is common within the sandstone part of the Hs facies. We see two mechanisms that can 

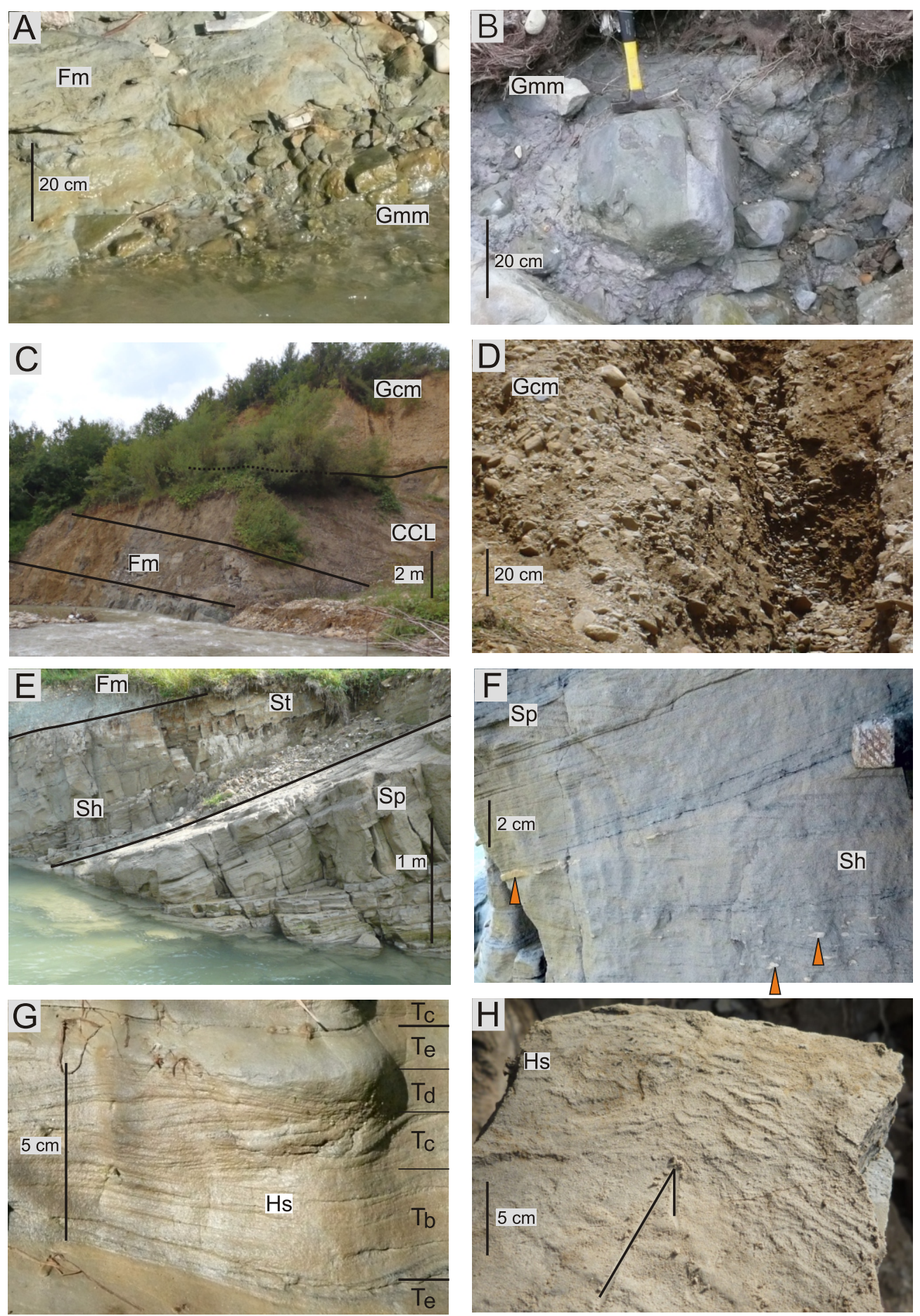

Fig. 5. Coarse-grained lithofacies of the Oravica River section

A - matrix-supported monomict breccia (lithofacies $\mathrm{Gmm}$ ) underlying fine clastic deposits (lithofacies Fm.); $\mathbf{B}$ - the same breccia consisting of angular and strongly weathered flysch clasts of diversified size (up to $40 \mathrm{~cm}$ ); C - clast-supported polymict conglomerate (lithofacies $\mathrm{Gcm}$ ) discordantly overlying fine clastic deposits (lithofacies Fm and $\mathrm{CCL}$ ); $\mathbf{D}$ - the same conglomerate shows disorganized, or rarely imbricated structure; $\mathbf{E}$ - thick-bedded sandstones with horizontal lamination (Sh), planar cross-bedding $(\mathrm{Sp})$ and trough cross-bedding (St), alternating with bluish massive siltstone (Fm); $\mathbf{F}$ - planar cross-bedded sandstone (Sp) and horizontally laminated sandstone (Sh) showing stratification marked by black wood detritus and grey mud intraclasts (marked by arrows); G - Bouma sequence in cyclic heterolithic sand-dominated deposits ( $\mathrm{Hs}$ ): Tb - parallel-laminated sandstone, Tc - cross-laminated sandstone, $\mathrm{Td}$ laminated siltstone, $\mathrm{Te}$ - massive siltstone and/or claystone; $\mathbf{H}$ - top surface of thin cross-laminated sandstone bed (Hs) covered by sinusoidal ripples; transport direction shown by arrow 

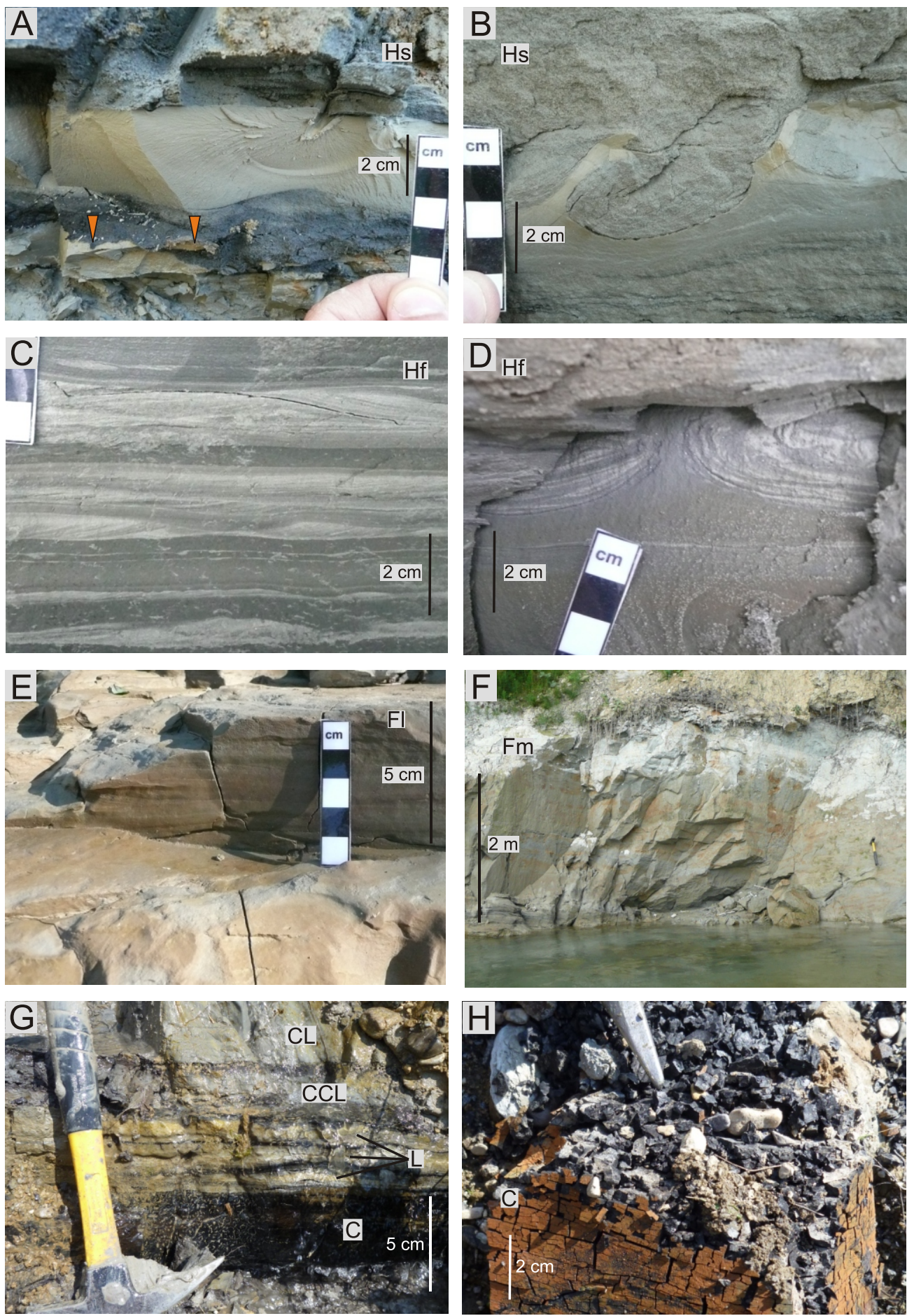

Fig. 6. Fine-grained lithofacies of the Oravica River section

A - soft-sediment disturbances at the claystone/sandstone boundary (marked by triangles); B - loadcasted base of sandstone, showing flame and ball-and-pillow structures within sand-dominated heterolithic deposits (Hs); C - fine ripple cross-lamination and horizontal lamination within heterolithic silt-dominated deposits (Hf); $\mathbf{D}$ - load cast structure within siltstone (Hf); $\mathbf{E}$ - subtly laminated siltstones (FI); F - massive siltstone bed $(\mathrm{Fm})$, over $3 \mathrm{~m}$ thick; $\mathbf{G}$ - coal $(\mathrm{C})$ bed within claystones $(\mathrm{CL})$ and coaly claystones $(\mathrm{CCL})$ containing also thin intercalations of limestone (L); $\mathbf{H}$ - coal bed (C) breaking-up into small, shiny pieces

explain the cyclic character of deposition: low-density current deposition in a body of standing water, or cyclic flooding of river overbanks.

Siltstone-dominated heterolithic deposit (Fig. 6C) represents a vertical stack of Bouma sequences (divisions Tc-e) consisting of siltstones and claystones. Beds are up to $2 \mathrm{~m}$ thick. Sequences Tc-d are up to $4 \mathrm{~cm}$ thick, and Te can be tens of centimetres thick. Individual load cast structures were observed at the bottom of these sequences (Fig. 6D). The lithofacies $\mathrm{Hf}$ lacks plant detritus. It has a unique two-colour scheme, i.e., the ripple-laminated division is light grey and the horizontal-laminated division is dark grey. This property makes lithofacies $\mathrm{Hf}$ easily distinguishable from lithofacies $\mathrm{Hs}, \mathrm{FI}$, and $\mathrm{Fm}$, which are generally grey or yellow. Sedimentary structures 

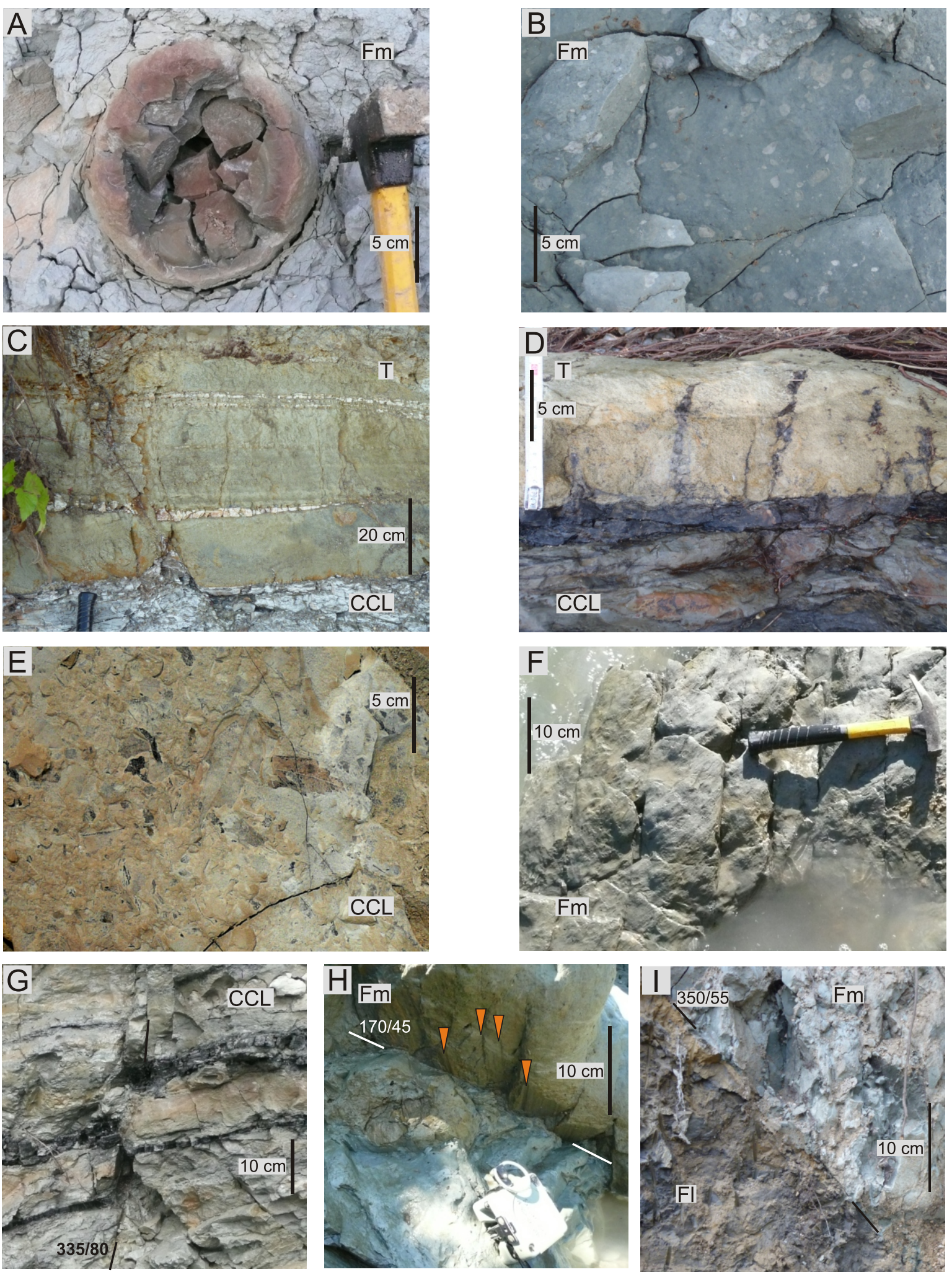

Fig. 7. Sedimentary, diagenetic and tectonic features of the Oravica River section

A - siderite concretion with septaria; B - unidentified gray small-scale concretions; C - stratified tuffite layer $(T), 40 \mathrm{~cm}$ thick, composed of three, amalgamated siltstone-claystone couplets; note the coaly claystone squeezed-up into small-scale fault; D - the same tuffite layer that is dissected by vertical injections of underlying coaly claystone; $\mathbf{E}$ - coaly claystone $(\mathrm{CCL})$, showing abundant leaves and plant detritus; $\mathbf{F}$ - regular fractures; $\mathbf{G}$ - small-scale normal fault within coaly claystones (CCL); $\mathbf{H}$ - slickenside striations (marked by triangles) at a normal fault F1 (see Fig. 3) surface; I - normal fault F2 (see Fig. 3) at the contact of two silty lithofacies: FI and Fm 


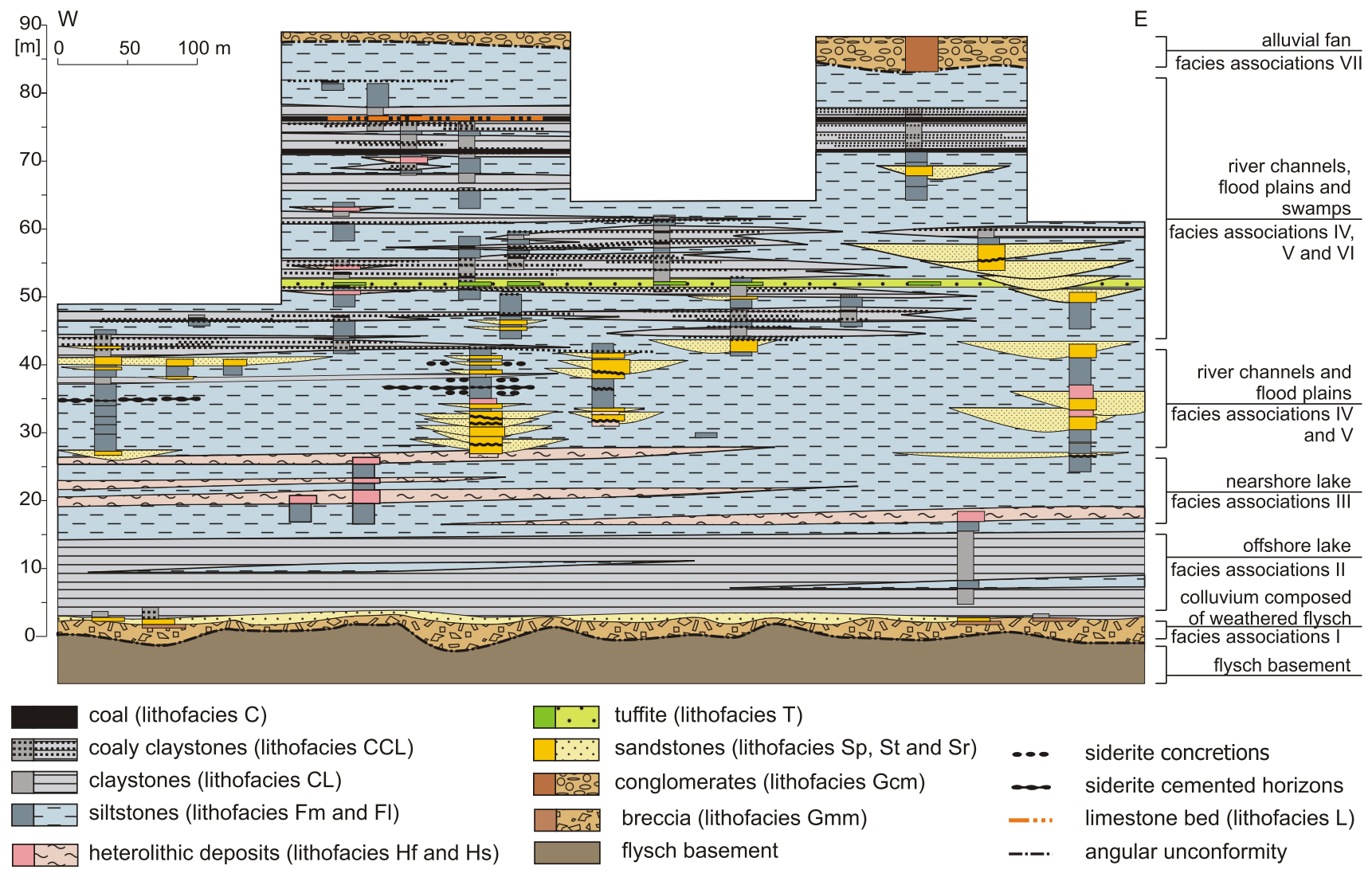

Fig. 8. Correlation scheme showing relationships between the facies associations distinguished in the Oravica River section

are very delicate and show no other disturbances, such as bioturbation or current erosion. Probably the same low-density current mechanism was responsible for cyclicity as for lithofacies Hs.

Laminated siltstone (Fig. 6E) consists of monotonous beds, up to $3 \mathrm{~m}$ thick, of clayey siltstone that is laminated and locally massive. Lamination is inferred from small changes of colour tone and the presence of partings along bedding planes. The lamina thickness varies from 2 to $20 \mathrm{~mm}$. Siltstones FI (like lithofacies $\mathrm{Hf}$ ) lack plant detritus, except for one small piece of drifted wood. The structure of siltstone $\mathrm{Fl}$ is undisturbed. The deposition mechanism is interpreted as suspension fallout. The lamination can be the result of successive pulses of weak currents carrying silty material.

Massive siltstone is the most common lithotype in the Oravica River section (Fig. 6F). It occurs in beds, up to $4 \mathrm{~m}$ thick, of siltstone and clayey siltstone, which generally lack any visible sedimentary structures. However, crude horizontal- and ripple cross-lamination is locally discernible due to subtle colour variations. In places, normal or inverse grading between siltstone (Fm) and claystone (CL) can be observed. The massive siltstone typically displays a grey-blue colour, which becomes red if it undergoes oxidation. The Fm lithofacies is locally rich in siderite concretions, with spheroidal cement textures indicative of a fresh-water environment (Fig. 7A), cemented horizons, and palaeosol calcitic structures (Fig. 7B). Concretion horizons generally follow bedding planes, which are tectonically tilted in the Oravica River section.

The thick beds accompanied by the absence of traces of erosion indicates continuous sedimentation. The massive structure may reflect rapid deposition from suspension during periods of high clastic material supply, e.g. flooding, although strong bioturbation cannot be entirely ruled out. The variety of diagenetic structures superimposed on the massive siltstone indicates that this facies underwent soil processes, but was interrupted by periodic clastic delivery thus preventing any full development of palaeosol zones. Nevertheless, the presence of siderite and calcitic structures allows for interpretation of these palaeosols as moderately developed (Retallack, 1988). This type of diagenetic structure is absent from other silt-rich lithofacies ( $\mathrm{Fl}$ and $\mathrm{Hf}$ ).

Massive claystone comprises $0.1-8.0 \mathrm{~m}$ thick beds of dark grey to grey-blue claystone, showing locally small admixtures of silt. This facies lacks sedimentary structures, although it may in places contain plant fossils aligned parallel to the bedding planes. Well-preserved leaves are scattered within the comminuted plant detritus. Thicker beds (up to $8 \mathrm{~m}$ ) occur within the lowermost part of the Oravica River section and suggest long periods of slow suspension settling. They lack plant fossils and their mostly dark grey colour may reflect the presence of dispersed, unoxidized organic matter. Massive claystone beds present within the upper part of the section beds are thinner (up to $1 \mathrm{~m}$ ), contain laminae rich in plant detritus, and are generally grey-blue (Fig. 6G).

Coaly claystone (Figs. $6 \mathrm{G}$ and $7 \mathrm{C}-\mathrm{E}, \mathrm{G}$ ) comprises thin (up to $20 \mathrm{~cm}$ ) claystone beds abounding in plant detritus, concentrated in dark grey to black laminae. Plant remains are mainly fine unidentifiable detritus, leaves, and rarely wood fragments. This facies originated in an environment which was abundant in water and subjected to a periodic supply of terrigenous matter, and associated with significant vegetation in the neighbourhood, such as an oxbow lake or riverbank strongly influenced by flooding.

Coal (Fig. 6G, H) occurs in black lithified beds $(5-30 \mathrm{~cm}$ thick) of phytogenic deposits. No plant remains can be identified macroscopically. The coal displays a massive to stratified struc- 
ture and tends to break into small brick-like pieces (Fig. 6H). The fracture surfaces are often shiny. These macroscopic features suggest that the coal underwent considerable burial (at the Ústie nad Priehradou site it is estimated to be 1150 m; Nagy et al., $1996)$ or strong microbiological processes. The coal beds locally contain very thin intercalations of limestone (lithofacies L; Fig. $6 \mathrm{G})$. The presence of coals can be related to strongly developed palaeosols (Retallack, 1988), or phytogenic accumulation in swamps.

Tuffite forms one layer (up to $40 \mathrm{~cm}$ thick) composed of three similar vertically amalgamated beds (Fig. 7C). Each bed shows normal grading from thick siltstone (up to $20 \mathrm{~cm}$ ) to thin (up to $2 \mathrm{~cm}$ ) claystone. The colour of the layer is white or yellow, although it becomes greenish when it is wet. This lithofacies is much more lithified, more porous, and accordingly less dense than any other siltstone and claystone lithofacies. The siltstone member of the layer mainly contains weathered, unidentified clasts, which altered into clay minerals and angular quartz grains. A variety of vertical structures cuts the layer. They may represent injections of underlying clays $(\mathrm{CL})$ and coaly clays (CCL) into fractures (Fig. 7C), or vertical holes left by the buried stems of plants (Fig. 7D). Although no typical pyroclastic material has been macroscopically recognized, the overall characteristics of this facies are consistent with an ash fall.

Limestone (Fig. 6G) is predominantly composed of authigenic microspar and spar calcite, and abounds in shell detritus - mainly molluscs. Organic matter is dispersed, or present as plant remains. The limestone exhibits large intercrystalline and intrashell porosities. It is grey, but turns pale-yellow on weathered surfaces. The limestone occurs as an up to $30 \mathrm{~cm}$ thick bed overlying coal. It seems that in this lithofacies calcium carbonate shells have been much better preserved than in other lithofacies. Considering the abundance of well-preserved mollusc shells, the limestone bed could have been deposited in a small ephemeral lake.

\section{FACIES ASSOCIATIONS}

The lithofacies were grouped into seven facies associations (FA) representing distinct depositional environments. The associations comprise Table 2.

The Oravica River section (Figs. 4 and 8) commences with colluvium (FA I), represented by a bed of lithofacies $\mathrm{Gmm}$ (up to $2 \mathrm{~m}$ thick) followed upwards by a bed of lithofacies Fm (up to $1 \mathrm{~m}$ thick). The latter contains preserved wood fragments and shell detritus, but lacks pedogenic structures (Fig. 5A). The debris-

Table 2

Facies associations and interpreted depositional environment

\begin{tabular}{|l|c|c|c|}
\hline Association & $\begin{array}{c}\text { Dominant } \\
\text { lithofacies }\end{array}$ & $\begin{array}{c}\text { Minor } \\
\text { lithofacies }\end{array}$ & Depositional environment \\
\hline FAl & Gmm & Fm & $\begin{array}{c}\text { colluvium composed } \\
\text { of weathered flysch rocks }\end{array}$ \\
\hline FAll & $\mathrm{CL}, \mathrm{FI}$ & - & offshore lake \\
\hline FAlll & $\mathrm{Hs}, \mathrm{Hf}$ & $\mathrm{CL}, \mathrm{Fl}$ & nearshore lake \\
\hline FAIV & $\begin{array}{c}\mathrm{Sh}, \mathrm{Sp}, \mathrm{St}, \\
\mathrm{Sr}\end{array}$ & $\mathrm{Fm}$ & sand-dominated fluvial channel \\
\hline FAV & $\mathrm{Fm}$ & $\mathrm{Sr}$ & floodplain \\
\hline FAVI & $\mathrm{CCL}$ & $\begin{array}{c}\mathrm{Fm}, \mathrm{CL}, \\
\mathrm{C}, \mathrm{L}, \mathrm{T}\end{array}$ & swamp \\
\hline FAVII & $\mathrm{Gcm}$ & - & gravel-dominated alluvial fan \\
\hline
\end{tabular}

flow origin of lithofacies Gmm and the angular shape of flysch clasts building up the breccia indicate short transportation. Although the exact sedimentary contact between underlying flysch rocks and the $\mathrm{Gmm}$ bed was not observed, it seems that the colluvium begins the ONT Basin fill. It is worth noting that similar lithofacies were identified in other outcrops within the ONT Basin: Miętustwo (Ciche), Chochołów, Lipnica Wielka, and Nové Ústie, all located near the flysch/ONT Basin border (Łoziński, 2011). A wood admixture here indicates land in the vicinity.

The colluvium is followed upwards by a fine-grained unit, several metres thick, which consists of massive claystone (facies $\mathrm{CL}$ ) interbedded with laminated siltstone (FI), and is interpreted as an offshore-lake facies association (FA II). The absence of coal horizons and siderite/calcitic structures distinguishes this facies association from floodplain (FA V) and swamp (FA VI) deposits. The dark grey colour of the mudrocks suggests dysoxic/anoxic bottom conditions in a lake that was likely to be a few metres deep. Very fine clastic material was deposited from suspension.

The offshore lake deposits grade upwards into heterolithic lithofacies ( $\mathrm{Hf}$ and $\mathrm{Hs}$ ), interbedded with massive claystones $(\mathrm{CL})$ and laminated siltstones $(\mathrm{FI})$. The frequency of occurrence of the two latter facies decreases upwards and this is accompanied by a coarsening-upwards trend. The characteristics are interpreted to indicate a gradual upwards transition into the nearshore-lake facies association (FA III). Deposition was generally from suspension in a body of standing water, and was periodically interrupted by low-density turbidity currents, as indicated by the occurrence of Bouma-type sequences within the heterolithic facies ( $\mathrm{Hf}$ and $\mathrm{HS}$ ). The total thickness of the lake deposits provides a crude estimate of the lake depth, which is a function of interplay between subsidence and sedimentation rates. Considering the thickness of lithofacies Hs (up to $3 \mathrm{~m}$ ), which is assumed to be rapidly deposited, and the total thickness of the lake deposits (up $20 \mathrm{~m}$ ), the depth of the lake may have varied from several to tens of metres.

The lake deposits are followed upwards by either a sanddominated fluvial channel or floodplain deposits (Figs. 4 and 8). The sand-dominated fluvial channel association (FA IV) consists of erosively-based, generally fining-up units, 0.5 to $3.0 \mathrm{~m}$ thick, composed of horizontally laminated (Sh), cross-bedded (Sp and $\mathrm{St}$ ), and ripple cross-laminated sandstones (Sr). The bodies are laterally limited and appear irregularly, at least at four levels within the middle part of the Oravica River section (Fig. 8). There are erosive basal contacts of the fluvial channel-fills against lithofacies $\mathrm{Fm}$ and $\mathrm{Hs}$, which indicates that the river cut into former lake deposits as well as into floodplain fines. It is also probable that rivers generated low-density turbidity currents in the lake.

The most common facies association in the Oravica River section is that of the floodplain (FA V). It is generally composed of massive siltstones (Fm), which contain local intercalations of plane and ripple cross-laminated sandstone (Sr). This facies association originated in extensive overbank areas subjected to frequent flooding.

The lowermost occurrence of the floodplain facies association in the Oravica River section is up to $10 \mathrm{~m}$ thick and reveals evidence of soil formation (Figs. 4 and 8). The rhizoliths point to the presence of rooted horizons, but no mature palaeosols developed at this stage. Other palaeosol structures present within this body, such as siderite concretions and cemented horizons, are probably results of later pedogenesis related to extensive plant vegetation and the phytogenic accumulation of coals $(C)$ and coaly claystones (CCL). Floodplain deposits continue into the 
upper part of the Oravica River section, but their thickness does not exceed $4 \mathrm{~m}$ and siderite concentrations are smaller.

Upwards in the section, the silt-dominated floodplain deposits are interbedded with alternations of massive siltstone (lithofacies $\mathrm{Fm}$ ), thin, grey-blue clay (CL), coaly clay (CCL), and coal (C), which are interpreted as a swamp facies association (FA $\mathrm{Vl}$; Fig. 8). This association records periods of decreased overbank flooding, which allowed plant vegetation to spread. Coal occurs in the upper part of the section, where it is in places interbedded with fresh-water limestone $(\mathrm{L})$, which reflects the transition of a swamp into a short-lived lake. Phytogenic elements are represented by the remains of palaeosols and could be evidence of an inland environment. The tuffite layer present in the association FA VI (Figs. 4, 7C, D and 8) is underlain by coaly clays and pure clays, which points to the high lateral diversity of environments at the time of the pyroclastic event.

The floodplain and swamp facies associations represent almost half of the thickness of the Oravica River section. This indicates that the balance between sedimentation and subsidence rates were stable for a long time. The continuous sedimentary record of associations $\mathrm{II}-\mathrm{VI}$ is cut by a regional angular unconformity (Figs. 4 and 8), at which the eroded fine-grained Neogene substrate is overlain by polymict conglomerates (lithofacies $\mathrm{Gcm}$ ), forming the gravel-dominated alluvial-fan facies association (FA VII). These conglomerates form the topmost element in the ONT Basin succession within the section studied, and document a younger stage in the basin evolution that postdated uplift and erosion of the underlying fine clastic deposits at the current southern margin of the basin. They also reflect the strong physical weathering and erosion of the Tatra Block (including its crystalline core) and Central Carpathian Paleogene Basin. Similar conglomerates cropping out south of the village of Čimhová are considered to be of Quaternary (Riss) age and derived from the Tatra Block and Central Carpathian Paleogene Basin (Gross et al., 1993a; BaumgartKotarba et al., 1996).

\section{PALAEOCURRENT DIRECTIONS}

The palaeocurrent data derived from the nearshore-lake facies association and the overlying fluvial cross-bedded channel deposits reveal a moderate scatter around the average direction towards the SSW (mean $208^{\circ}$, standard deviation $48^{\circ}$; Fig. 4). The results suggest a common dispersal system, linking fluvial delivery with the lake that was fed from the NNE and deepened towards the SSW. The relatively high spread of crossbedding dip directions may support the notion of the meandering nature of the fluvial channels.

\section{SUMMARY OF ENVIRONMENTAL EVOLUTION}

The Oravica River section provides evidence of a dynamic environment. Basin initiation was accompanied by the gravitational collapse of a weathered flysch substrate and was followed by the development of a lake. The lake depth may have varied from several to tens of metres and was most likely of considerable regional extent. It was filled with very fine terrigenous material, delivered mainly by fluvially-generated low-density turbidity currents. The mean palaeoflow was towards the SSW, which was probably the direction of the lake deepening. The nearest lacustrine shoreline is expected to have been located north-eastwards off the study area. The lake margin was of clastic type, locally with stands of macrophytes, and with no obvious evidence of wave activity.
The lake evolved gradually into a muddy floodplain, crossed by meandering fluvial channels. The maximum width of river channels probably did not exceed tens of metres. Ephemeral palaeosols developed between flooding events. A volcanic event proceeding in three pulses resulted in an ash fall, which covered a sparsely vegetated and locally marshy floodplain. The post-volcanic evolution of the alluvial plain is characterized by the development of swamps and local coal formation. The Neogene sedimentation ended by tilting, followed by the emplacement of Quaternary alluvial fans, reflecting a high palaeorelief and strong physical weathering in the Central Carpathian Paleogene Basin and Tatra Block units.

\section{DISCUSSION}

The interpretation presented by Watycha $(1976,1977)$ assumes that the ONT Basin fill is composed of cyclically organized lens-shaped sequences up to $20 \mathrm{~m}$ thick. The full sequence is composed, in ascending order, of conglomerates, conglomerates interbedded with sandstones, normally-graded sandstones intercalated with siltstones rich in plant detritus, laminated siltstones with claystone admixture, and finally pure claystones. According to this author, conglomerate beds are common near the basin margin, whereas its central part consists mainly of fine-grained deposits.

Such a pattern does not fit the Neogene strata in the Oravica River section. Although the study area is located at the basin margin, conglomerates are absent up to the hiatus level (except the basal breccias $\mathrm{Gmm}$ of debris flow origin). Moreover, much of the section reveals lacustrine claystones that coarsen upwards through a turbidite-bearing heterolithic interval into fluvial deposits, which together implies a gradual filling of the lake. The overlying alternation of the facies associations $\mathrm{IV}, \mathrm{V}$, and $\mathrm{VI}$ appears to reflect largely autocyclic mechanisms of alluvial-plain formation, superimposed on regional tectonic subsidence. It needs to be stressed that the tracing of Watycha's $(1976,1977)$ lithostratigraphic units into the Oravica River section meets difficulties due to the poor preservation of mollusc shells, which are the basis for his stratigraphy.

The nature of the borders of the ONT Basin has been widely discussed (e.g., Baumgart-Kotarba, 1996; Pomianowski, 2003; Struska, 2008; Tokarski et al., 2012), because their character is an important prerequisite to properly interpret the genesis and structural evolution of the basin. Its rhomboidal shape suggests that it originated as a pull-apart basin, or above some type of fault-releasing bend, but the location of the master strike-slip fault zone has been variously interpreted. The Oravica River section provides some new, important data on this problem. The presence of the lake with offshore fine-grained sedimentation needs a depression several kilometres wide. The maximum lake extent is impossible to estimate, although the SSW-ly palaeoflow suggests that it spread more to the south. The Oravica River section also lacks marginal facies typical of fault-bounded basins (Birkenmajer, 1954; Watycha, 1976), such as alluvial fan conglomerates. The topmost conglomerate (lithofacies $\mathrm{Gcm}$ ) is probably of Quaternary age (BaumgartKotarba et al., 1996) and hence cannot be linked to the early stage of basin formation.

All these premises suggest that the basin originally extended farther towards the south. Moreover, the high coal alteration degree and the deep burial of the basin fill (Nagy et al., 1996) suits the hypothesis that the Neogene ONT Basin was wider than it is at present. If the basin originated as a faultbounded graben, its marginal fault zone would have to be lo- 
cated farther to the south. It follows from the above that tectonic structures observed at the southern border, such as the normal fault exposed in the Czarny Dunajec River (Tokarski et al., 2012), can be related to an episode of uplift and erosion that affected the southern part of the basin fill and resulted in the angular unconformity below the Quaternary conglomerate. Such an interpretation fits well with the basin evolution model presented by Tokarski et al. (2012).

The other structural aspect of the Oravica River section is bedding tilted at ca. $20^{\circ}$ to the north. Because Neogene deposits overlie the flysch basement it is probable that tilting involved the basement rocks and was regional in scale. Tilting and erosion can explain the linear character of the present-day ONT Basin margins. The gravity model of section G2 crossing our study area shows the basin floor inclined at an average angle of $19^{\circ}$ towards the north (Pomianowski, 2003). This dip has been interpreted in terms of a series of normal faults, displacing and rotating the originally horizontal base of the basin fill (Pomianowski, 2003). In our opinion, a tilted basin floor is also a viable explanation, which corresponds well to the structural dip measured in the Oravica River section.

The concept of a larger southward extent of the basin at the time of sedimentation and a later northward tilt raises the question of a depocenter migration. Although the data is insufficient, we hypothesize that the sedimentation began southwards off the present-day deepest point of the basin and spread gradually to the north. Such a northwards-advancing depocenter would also be consistent with the interpretations proposed, among others, by Watycha (1976), Baumgart-Kotarba (2001) and Tokarski et al. (2012).

A marine influence on deposition in the ONT Basin was widely discussed (e.g., Birkenmajer, 1954), based on the presence of Early Miocene deposits containing marine foraminifera and ostracods. However, Cieszkowski (1995) interpreted these deposits as belonging structurally to the Magura Unit. The presence of mixed marine microfossils of Cretaceous to Lower Miocene age within the ONT Basin could have been the result of redeposition (unpublished report of Garecka and Szydło, 2013). The range of depositional settings documented in the
Oravica River section, together with the abundance of wood fragments, points clearly to the non-marine origin of the basin fill in this area. This is further supported by the spheroidal textures of siderite concretions, because such textures appear neither in fully marine, nor in brackish-water environments (Bojanowski and Clarkson, 2012).

\section{CONCLUSIONS}

The investigations conducted in the Oravica River section resulted in the following conclusions concerning this part of the ONT Basin:

- The Oravica River section reveals the basal part of the ONT Basin fill.

- The palaeoenvironment evolved from a weathering flysch surface with debris flows, followed by a fresh-water lake, rivers, and then repetitively flooded overbanks with swamps. This environment was disturbed by volcanic ash fall events.

- Palaeotransport direction was to the SSW and records the process of lake filling fed by rivers.

- The ONT Basin spread more to the south and the current basin extent may be erosional.

- The Oravica River section documents structural inversion, from subsidence and deposition to uplift, tilt, and erosion of the fine-clastic Neogene body. This was followed by the deposition of conglomerates, with material from the Tatra Block and CCPB eroded under strong physical weathering conditions.

- Considerable thermal/biochemical processes were involved during coal diagenesis

Acknowledgements. The study was financed by a National Science Centre (NCN) grant no. 2011/01/B/ST10/07591. Reviews by M. Kováč and A. Świerczewska and editorial comments and suggestions by S. Porebski helped to improve the manuscript and are greatly appreciated by the authors.

\section{REFERENCES}

Andrusov, D., 1938. Geologický výskum vnitřního bradlového pásma v Západních Karpatech. III. Tektonika (in Czech). Rozpravy Štátnego geologickego Ústavu ČSR, 9

Bac-Moszaszwili, M., 1993. Structure of the western termination of the Tatra massif (in Polish with English summary). Annales Societatis Geologorum Poloniae, 63: 167-193.

Baumgart-Kotarba, M., 1996. On origin and age of the Orava Basin, West Carpathians. Studia Geomorphologica CarpathoBalcanica, 30: 101-116.

Baumgart-Kotarba, M., 2001. Continuous tectonic evolution of the Orava basin from Late Badenian to the present-day. Geologica Carpathica, 52: 103-110.

Baumgart-Kotarba, M., Michalik, M., Paszkowski, M., Świerczewska, A., Szulc, J., Uchman, A., 1996. Provenance and age of coarse clastic alluvial deposits at Čimhova in the Orava Basin, Western Carpathians, Slovakia. Polskie Towarzystwo Mineralogiczne - Prace Specjalne, 7: 68-72.

Baumgart-Kotarba, M., Marcak, H., Marton, E., Imre, G., 2004. Rotation along transverse transforming Orava strike-slip fault in the light of geomorphological, geophysical and paleomagnetic data (Western Carpathians). Geologica Carpathica, 55: 219-226.
Birkenmajer, K., 1954. Geological investigations of Podhale Neogene (Central Carpathians) (in Polish with English summary). Biuletyn Instytutu Geologicznego, 86: 59-79.

Birkenmajer, K., 1960. Geology of the Pieniny Klippen Belt of Poland. Jahrbuch der Geologischen Bundesanstalt, 103: 1-36.

Birkenmajer, K., Oszczypko, N., 1989. Cretaceous and Palaeogene lithostratigraphic units of the Magura Nappe, Krynica Subunit, Carpathians. Annales Societatis Geologorum Poloniae, 59: 145-181.

Bojanowski, M.J., Clarkson, E.N.K., 2012. Origin of siderite concretions in microenvironments of methanogenesis developed in sulfate reduction zone: an exception or a rule? Journal of Sedimentary Research, 82: 585-598.

Cieszkowski, M., 1995. Marine Miocene deposits close to Nowy Targ and their importance for determining age of the Orava-Nowy Targ basin, south Poland (in Polish with English summary). Kwartalnik AGH Geologia, 21: 153-168.

Cieszkowski, M., Oszczypko, N., Zuchiewicz, W., 1989. Upper Cretaceous siliciclastic carbonate turbidites at Szczawa, Magura Nappe, West Carpathians, Poland. Bulletin of the Polish Academy of Sciences, Earth Sciences, 37: 231-245. 
Garecka, M., 2005. Calcareous nannoplankton from the Podhale Flysch (Oligocene-Miocene, Inner Carpathians, Poland). Studia Geologica Polonica, 124: 353-370.

Garecka, M., Szydło, A., 2013. Analiza mikropaleontologiczna nt. Oznaczenie mikrofaunistyczne (otwornic) i nanoplanktonu wapiennego ze szczególnym uwzglednieniem wieku i stopnia redepozycji materiału (45-5605-1251-10-0) (in Polish). Polish Geological Institute-National Research Institute, Kraków, unpublished.

Gross, P., Köhler, E., Haško, J., Halouzka, R., Mello, J., Nagy, A. 1993a. Geológia juźnej a východnej Oravy (Geology of southern and eastern Orava). Śtátny Geologický Ústav Dionýza Štúra, Bratislava.

Gross, P., Filo, I., Halouzka, R., Haško, J., Havrila, M., Kováč, P., Maglay, J., Mello, J., Nagy, A., 1993b. Geological map of the southern and eastern part of Orava. Ministerstvo Životného Prostredia - Štátny Geologický Ústav Dionýza Štúra.

Janků, J., Pospíšil, L., Vass, D., 1984. Contribution of remote sensing to the knowledge of West Carpathians structure (in Slovak with English summary). Mineralia Slovaca, 16: 121-137.

Kołcon, I., Wagner, M., 1991. Brown coal from Neogene sediments of the Orawa-Nowy Targ basin - petrological study (in Polish with English summary). Geological Quarterly, 35 (3): 305-322.

Kováč, M., Nagymarosy, A., Oszczypko, N., Csontos, L., Ślączka, A., Marunteanu, M., Matenco, L., Márton, E., 1998. Palinspastic reconstruction of the Pannonian-Carpathian region during the Miocene. In: Geodynamic Development of the Western Carpathians (ed. M. Rakús): 189-217. Geological Survey of Slovak Republic, Bratislava.

Kováč, P., Hók, J., 1993. The Central Slovak Fault System - the field evidence of a strike slip. Geologica Carpathica, 44: 155-159.

Kukulak, J., 1998. Sedimentary characteristics of the topmost deposits, Domański Wierch alluvial cone (Neogene/Pleistocene), Orava Depression, Polish Carpathians (in Polish with English summary). Studia Geologica Polonica, 111: 93-111.

Lexa, J., Bezák, V., Elečko, M., Mello, J., Polák, M., Potfaj, M., Vozár, J., 2000. Geological map of the Western Carpathians and adjacent areas, 1:500 000. Geological Survey of Slovak Republic, Bratislava.

Ludwiniak, M., 2010. Multi-stage development of the joint network in the flysch rocks of western Podhale (Inner Western Carpathians, Poland). Acta Geologica Polonica, 60: 283-316.

Łoziński, M., 2011. Geology of Neogene deposits in the zone of the Orava-Nowy Targ Basin contacts with the Podhale Synclinorium, Čimhová and Chochołów regions (in Polish with English summary). Msc thesis, Faculty of Geology, University of Warsaw.

Łój, M., Madej, J., Porzucek, S., Zuchiewicz, W., 2009. Monitoring geodynamic processes using geodetic and gravimetric methods: an example from the Western Carpathians (South Poland). Geologia, 35: 217-247.

Malata, E., Malata, T., Oszczypko, N., 1996. Litho- and biostratigraphy of the Magura Nappe in the eastern part of the Beskid Wyspowy Range (Polish Western Carpathians). Annales Societatis Geologorum Poloniae, 66: 269-283.

Mastella, L., 1975. Flysch tectonic in the eastern part of the Podhale Basin (Carpathians, Poland) (in Polish with English summary). Annales Societatis Geologorum Poloniae, 45: 361-401.

Miall, A.D., 2000. Principles of Sedimentary Basin Analysis. Springer, Berlin-Heidelberg

Miall, A.D., 2006. The Geology of Fluvial Deposits: Sedimentary Facies, Basin Analysis and Petroleum Geology. Springer, Berlin.

Nagy, A., 1993. Litológia a stratygrafia neogénnych sedimentov Oravskiej kotliny. In: Geológia juźnej a východnej Oravy (ed. P. Gross): 117-121. Štátny Geologický Ústav Dionýza Štúra, Bratislava

Nagy, A., Vass, D., Petrik, F., Pereszlényi, M., 1996. Tectogenesis of the Orava Depression in the light of latest biostratigraphic investigations and organic matter alteration studies. Slovak Geological Magazine, 1: 49-58.

Olszewska, B., Wieczorek, J., 1998. The Paleogene of the Podhale Basin (Polish Inner Carpathians) - micropaleontological perspective (in Polish with English summary). Przegląd Geologiczny, 46: 721-728.

Oszast, J., Stuchlik, L., 1977. The Neogene vegetation of the Podhale (West Carpathians, Poland) (in Polish with English summary). Acta Palaeobotanica, 18: 45-86.

Plewa, K., 1969. An analysis of gravel covers in the Domańsk Wierch Fan (in Polish with English summary). Folia Geographica, Series Geographica-Physica, 3: 101-115.

Pomianowski, P., 2003. Tectonics of the Orava-Nowy Targ Basin results of the combined analysis of the gravity and geoelectrical data (in Polish with English summary). Przegląd Geologiczny, 51: 498-506.

Pospíšil, L., 1990. The present possibilities of identification of shear zones in the area of the West Carpathians (in Slovak with English summary). Mineralia Slovaca, 22: 19-31.

Pospíšil, L., Nemčok, J., Graniczny, M., Doktór, S., 1986. Contribution of remote sensing to the identification of the strike-slip faults in the West Carpathians. Mineralia Slovaca, 18: 385-402.

Reading, H.G., 1996. Sedimentary Environments: Processes, Facies and Stratigraphy. Wiley-Blackwell.

Retallack, G.J., 1988. Field recognition of paleosols. GSA Special Paper, 216: 1-20

Roth, Z., Benešová, E., Čechovič, V., Eliáš, M., Hanzlíková, E., Chmelík, F., Matějka, A., Pícha, F., 1963. Vysvetlivky k prehladnej geologickej mape ČSSR 1:200 000, M-34-XX Trstená. Geofond, Bratislava.

Sikora, W., Wieser, T., 1974. Utwory piroklastyczne w utworach neogeńskich śródgórskiej niecki Orawy-Nowego Targu. Kwartalnik Geologiczny, 18 (2): 441-443.

Sotak, J., 1998a. Sequence stratigraphy approach to the Central Carpathian Paleogene (Eastern Slovakia): eustasy and tectonics as controls of deep sea fan deposition. Slovak Geological Magazine, 4: 185-190.

Sotak, J., 1998b. Central Carpathian Paleogene and its constraints. Slovak Geological Magazine, 4: 203-211.

Struska, M., 2008. Neogeńsko-czwartorzedowy rozwój strukturalny Kotliny Orawskiej w świetle badań geologicznych, geomorfologicznych oraz teledetekcyjnych (in Polish). PhD thesis, Faculty of Geology, University of Cracow.

Śmigielski, M., Stuart, F.M., Persano, C., Krzywiec, P., Sinclair, H.D., Pisaniec, K., Sobień, K., 2011. Neogene exhumation of the Northern Carpathians revealed by low temperature termochronology. 7th TOPO-EUROPE Workshop. Davos, Switzerland, www.esd.ethz.ch/topoeurope7/ab

Świerczewska, A., 2005. The interplay of thermal and structura histories of the Magura Nappe (Outer Carpathians) in Poland and Slovakia. Mineralogia Polonica, 36: 91-144.

Tokarski, A.K., Zuchiewicz, W., 1998. Fractured clasts in the Domański Wierch series: Contribution to structural evolution of the Orava Basin (Carpathians, Poland) during Neogene through Quaternary times (in Polish with English summary). Przegląd Geologiczny, 46: 62-66.

Tokarski, A.K., Świerczewska, A., Zuchiewicz, W., Starek, D., Fodor, L., 2012. Quaternary exhumation of the Carpathians: a record from the Orava-Nowy Targ Intramontane Basin, Western Carpathians (Poland and Slovakia). Geologica Carpathica, 63: 257-266

Watycha, L., 1976. The Neogene of the Orava-Nowy Targ Basin (in Polish with English summary). Kwartalnik Geologiczny, 20 (3): 575-585.

Watycha, L., 1977. Objaśnienia do Szczegółowej Mapy Geologicznej Polski w skali 1:50 000, arkusz Czarny Dunajec (in Polish). Wyd. Geol., Warszawa.

Westwalewicz-Mogilska, E., 1974. Tuffite in the Neogene molasse of the Domański Wierch alluvial cone. Bulletin of the Polish Academy of Sciences, Earth Sciences, 22: 173-178.

Wiewióra, A., Wyrwicki, R., 1980. Clay minerals of the Neogene sediments in the Orava-Nowy Targ basin (in Polish with English summary). Kwartalnik Geologiczny, 24 (2): 333-348. 